\title{
Critical audit matters and stock price crash risk
}

\author{
Xiaoqiang Zhi ${ }^{1}$ and Zuming Kang ${ }^{2^{*}}$ D
}

\author{
* Correspondence: Nicole9493@ruc. \\ edu.cn \\ ${ }^{2}$ Department of Finance, Business \\ School, Renmin University of China, \\ Room 0439, Pinyuan 3 Building in \\ Renmin University of China, No.59 \\ Zhongguancun Street, Beijing, \\ Haidian District, China \\ Full list of author information is \\ available at the end of the article
}

\begin{abstract}
Using manually collected data on the number and category of critical audit matters (CAMs) in the period 2016-2017, we investigate the hitherto unexplored questions of whether CAMs affect firm-specific crash risk, how CAMs influence crash risk in the Chinese capital market, and recognize CAMs that contain incremental information. Our findings are as follows: (1) Crash risk decreases after implementing the new audit standard requiring the disclosure of CAMs; (2) CAMs release negative information and change the capital market information environment; (3) only corporateidiosyncratic CAMs contain incremental information; (4) crash risk is mitigated only by CAMs disclosed by companies with a high shareholding of institutional investors. The main conclusion of our study is a positive assessment of the new audit standard and of CAMs in terms of protecting the interests of investors and strengthening the stability of the capital market to provide a new perspective for supervising the implementation of the new audit standard.
\end{abstract}

Keywords: Critical audit matters (CAMs), Crash risk, Incremental information, New audit standard, Corporate-idiosyncratic CAMs

\section{Introduction}

Traditional audit reports contain insufficient information and result in a large information gap between users' needs and what is available in the reports. This has been criticized severely by users in the context of the global financial crisis in 2008 (Tang 2015). The critical audit matters (CAMs) proposal is an important measure to narrow the information gap and reduce information asymmetry, as firm risk information was not disclosed in any form in audit reports before. Three important time points mark the development of the new audit standard and CAMs. The first was when the financial reporting committee (FRC) requested Certified Public Accountants (CPAs) to expand the content of audit reports in 2012, to include a discussion of material misstatement risk, materiality level, and audit universe, which was formally implemented in 2013 (FRC (Financial Reporting Council) 2013). The second was when the International Audit and Assurance Standards Board (IAASB) officially issued the new audit standard requiring CPAs to disclose CAMs in audit reports in early 2015; this was the first time that CAMs appeared in the audit standards formally. Finally, the Ministry of Finance of China issued the new audit standard (Chinese CPA Audit Standard No. 1504-

(c) The Author(s). 2021 Open Access This article is licensed under a Creative Commons Attribution 4.0 International License, which permits use, sharing, adaptation, distribution and reproduction in any medium or format, as long as you give appropriate credit to the original author(s) and the source, provide a link to the Creative Commons licence, and indicate if changes were made. The images or other third party material in this article are included in the article's Creative Commons licence, unless indicated otherwise in a credit line to the material. If material is not included in the article's Creative Commons licence and your intended use is not permitted by statutory regulation or exceeds the permitted use, you will need to obtain permission directly from the copyright holder. To view a copy of this licence, visit http://creativecommons.org/licenses/by/4.0/. 
Communicating Key Audit Matters in the Audit Reports) on December 23, 2016 to comply with the reform wave of international auditing standards.

It has been nearly 4 years since the new audit standard was implemented in the Chinese capital market, and research on CAMs has been ongoing since. The most important issue that attracts the attention of scholars and practitioners is whether CAMs are a critical issue for the Chinese capital market; whether CAMs can clarify the information environment, significantly alter the decisions of capital market participants, and cause a capital market response and reaction by way of its contribution of incremental information. Some studies based outside of China have found that CAMs have incremental information (Christensen et al. 2014), while others have argued that they do not have it, and that they do not change investors' decisions and lead to market reaction (Bédard et al: Costs and benefits of reporting key audit matters in the audit report: The French Experience, unpublished; Bédard et al: Analysis of the consequences of the disclosure of key audit matters in the audit report, unpublished; Elizabeth et al. 2018). However, relevant domestic studies in China agree that CAMs contain incremental information that causes a positive market response (Wang et al. 2018), reduces stock price synchronization, and improves asset pricing efficiency (Wang and Wang 2019), reflecting their value in maintaining the stability of the capital market. The problem with CAMs and the new audit standard seems to be a momentous issue not only for the audit report and audit procedure but also for the immature capital market in China.

There are the interesting phenomenon that positive and negative stock returns in capital markets are not symmetric (Bekaert and Wu. 2000), and this phenomenon may be more prominent in the Chinese capital market (Ye et al. 2019) due to its relatively short history, systemic defects, and its immaturity. As a result, crash risk and positive jump factors such as corporate governance, market manipulation behavior (Chan 2003), and investors' irrational overreaction to information (Hirshleifer 2001) may be magnified. For example, Ye et al. (2019) find that stocks with positive jump in the Chinese capital market exhibited a low return on assets (ROA), a high market-to-book ratio, and a low long-term abnormal return. These stocks carry a greater crash risk and higher return volatility in subsequent periods; a short-term stock price upsurge is followed by a sharp decline and consequent losses to investors, leading to temporary gains but permanent losses. Empirically, the return rates of stocks in the Chinese capital market reflect the feature of "long time in bear market and short time in bull market," which indicates short-lived prosperity in asset price followed by a severe crash and long-term dismal performance. The Shanghai Composite Index dropped abruptly from 6124 points in October 2007 to 1664 points in October 2008. The degree of the crash was astonishing. In 2015, the stock disaster in the Chinese capital market also resulted in extremely rare phenomena of thousands of shares limit up and thousands of shares limit down. These events are evidence of the dramatic volatility of Chinese capital market and the obvious asymmetry of positive and negative stock returns. Acute crash risk not only damages the interest and confidence of investors severely, but also poses tremendous obstacles to achieving effective operation by the Chinese capital market. Therefore, crash risk is a key part of a discussion on investor protection, corporate governance, and financial market stability.

Relevant research in the field of finance suggests two important sources of crash risk: the agency problem and the information environment. Improved corporate governance 
can significantly suppress the opportunistic behavior of management and therefore reduce the accumulation of bad news and improve the quality of information disclosure, addressing crash risk at source. Releasing negative incremental information related to corporate risk to the capital market and changing the information environment may also ease the downward pressure on stock prices by reducing investor sentiment and stock price bubbles. Audit is an important external mechanism for corporate governance, which plays a significant role in alleviating agency problems and crash risk (Fan and Wong 2005; Jensen and Meckling 1976; Jiang and Yi 2013; Wan 2015). The implementation of the new audit standard to achieve higher audit quality (Reid et al: Impact of auditor and audit committee report changes on audit quality and costs: Evidence from the United Kingdom, unpublished; Yang et al. 2018) is considered an important measure to strengthen audit as an external corporate governance mechanism, which may inhibit opportunistic behavior by management. The release of negative information through CAMs can also enhance the information environment and alleviate the downward pressure on stock prices caused by the accumulation of bad news. Therefore, in the Chinese capital market environment of great volatility, the important question is: Can CAMs reduce stock price crash risk by alleviating the agency problem and changing the market information environment? To explore the issue, this study utilizes the treatment and control groups arising naturally from the relevant policy on and regulation of CAMs. It uses data from 2015 and 2016-one year before and after the implementation of the standard-to construct a difference-in-differences (DID) model to test the impact of the disclosure of CAMs on crash risk.

We also find a special circumstance to determine the mechanism of this effect based on the unique connotation of stock price crash risk. It demonstrates that negative incremental information through CAMs changes the information environment, thus affecting investor sentiment preventing the formation of stock bubbles, and reducing crash risk in the end. Specifically, we use the opposite of crash risk-positive stock price jump-as the explanatory variable and confirm that the incremental information in CAMs is negative. We find that when management has a motivation to conceal good news, CAMs have no significant effect on positive stock price jump. This suggests that CAMs have an asymmetric effect on crash risk and positive jump, which shows that negative incremental information in CAMs causes a market reaction that is reflected in the attenuation of crash risk.

In 2017, China began to fully implement the new audit standard on CAMs. We use manually collected data on CAMs in the 2017 audit reports to explore whether the number and category of CAMs can influence its impact on crash risk. Although the implementation of the new audit standard significantly reduces crash risk, an increase in CAMs was found to have no inhibitory effect on crash risk. When industry-homogeneous CAMs were eliminated, however, increasing the number of CAMs had a negative effect on crash risk. Therefore, we argue that only a section of CAMs, which contains characteristic information on a specific company, constitutes incremental information that can enhance information communication.

Following the mechanism test and further research, we explore whether different types of audit report users have different impacts on the effect of CAMs on crash risk. Due to their professional capability, institutional investors may suffer less from limited 
attention than individual investors, making it necessary to differentiate between individual and institutional investors in handling the information contained in CAMs. The results show that CAMs work only when there is a high proportion of institutional investors, which implies that the incremental information in CAMs is more likely to be utilized by institutional investors for it to affect stock prices.

Our study contributes to the existing literature in several ways. First, it is a pioneering study that examines the effect of CAMs on crash risk, and thus enriches the literature. The fundamental results not only confirm that CAMs are a factor in crash risk but also show that the new audit standard plays a significant role in stabilizing the Chinese capital market. Second, the mechanism test demonstrates that CAMs constitute negative incremental information, which fills a gap in recent research on this issue, and also provides a new perspective for future research on the impact of CAMs. Third, and most importantly, we propose the view that a high number of CAMs does not equate to a high communication value of audit reports, because only corporate-idiosyncratic CAMs have incremental information. This viewpoint is consistent with doubts raised by some policymakers and scholars on the efficacy of CAMs. Furthermore, our conclusions have practical implications for capital markets. From the perspective of CPAs and accounting firms, the relevant conclusions serve to caution CPAs about CAMs' wider influence, and about the need for attention to the information content in audit reports rather than its external manifestation; such a focus would alleviate information asymmetry and ultimately stabilize the capital market. Report users, including analysts and investors, should fully identify and utilize the useful information in CAMs to improve the quality of their research reports or investment decisions. Regulatory authorities can take advantage of the new policy in guiding capital market participants towards a stable market order. We believe these implications to be of significant value for future research.

\section{Literature review and hypothesis development Prior research on CAMs}

Research on CAMs and the implementation of the new audit standard has been carried out both at home and abroad. The current literature discusses mainly three aspects of CAMs.

The first aspect is the impact of CAMs on the audit responsibility of CPAs. Kachelmeier et al. (2014) find that the disclosure of CAMs is equivalent to a disclaimer by CPAs, which mitigates their audit responsibility. Brasel et al. (2016) and Han and Zhang (2018) reach a similar conclusion that the disclosure of CAMs might reduce the probability that a jury assesses a CPA as negligent. There is also research, however, that draws an opposite conclusion. For example, Gimbar et al. (2018) find that disclosure of CAMs could increase CPAs' potential audit responsibilities by revealing their working procedures to the public. In addition, Vinson et al. (2018) demonstrate that different treatments on CAMs, including removing or disclosing the same matters for several years in a row, might increase the likelihood of a jury's assessment of a CPA as negligent.

The second aspect is whether and how capital markets and investors are influenced by CAMs globally. Conclusions of foreign studies on this issue are controversial. Some 
studies believe that CAMs have incremental information that can significantly change the investment decisions of non-professional investors and reduce their willingness to invest (Christensen et al. 2014). However, others find that CAMs do not contain incremental information and that investors' decisions and market reaction are not influenced by them (Bédard et al: Costs and benefits of reporting key audit matters in the audit report: The French Experience, unpublished; Bédard et al: Analysis of the consequences of the disclosure of key audit matters in the audit report, unpublished; Elizabeth et al. 2018). Interestingly, recent Chinese research agrees that CAMs have incremental information leading to positive market reaction (Wang et al. 2018), lower stock price synchronization (Wang and Wang 2019), and lower earnings value relevance (Chen and Zhang 2019).

The last aspect is the impact of CAMs on the audited entity and its behavior. Specifically, disclosing CAMs can significantly reduce earnings management by executives (Klueber et al. 2016) and thus improve audit quality (Reid et al: Impact of auditor and audit committee report changes on audit quality and costs: Evidence from the United Kingdom, unpublished; Yang et al. 2018). Summarizing the above results, there has been a wide divergence in research conclusions on some aspects of CAMs.

Our study focuses on the issue of incremental information in CAMs. In the past, the discussion on incremental information in audit reports focused on going-concern opinions. Similar to the reform on CAMs in recent years, the going-concern opinion paragraph in the audit report was first required by American Institute of Certified Public Accountants (through SAS No. 59 Going-Concern Opinions) in 1988 to provide investors with incremental information for decision making. Relevant studies have shown that the information in going-concern opinions improves the communication value of audit reports in addition to helping investors predict the bankruptcy of a company earlier (Fleak and Wilson 1994). Following the implementation of SAS No. 59 GoingConcern Opinions, firms under financial stress were more likely to be issued audit reports with the relevant paragraphs of going-concern opinions (Raghunandan and Rama 1995), and the communication value was reflected in lower negative abnormal returns to investors (Krishnagopal and David 2010); the increased degree of unexpected negative perception of such information by investors aggravated the abnormal state of these negative returns (Jones 1996). Blay et al. (2011) also find that investors' valuation of a firm decreased after the firm was issued with the relevant paragraphs of going-concern opinions in the audit report, which meant that the paragraphs had incremental information that the market itself interpreted as risk information (Holderwebb and Wilkins 2000). Similar reforms and studies on going-concern opinions in the past may offer some evidence for the present research on CAMs. Furthermore, China duly adopted the new audit standard on CAMs. In addition to the several years of data produced by the implementation of the standard, the treatment and control groups that arise naturally from the policy make the Chinese capital market an ideal place to explore many issues of CAMs-this was another major motivation for this study.

\section{CAMs and stock price crash risk}

The mainstream view on crash risk in the field of finance is that crash risk originates from the accumulation of bad news caused by management intentionally concealing 
bad news for specific purposes, such as self-interest. When the bad news is forcibly released, the stock price starts to fluctuate erratically and finally collapses as the negative information reaches the market.

The discussion and research on crash risk stem from two aspects. The first is contributing factors to crash risk. Information environment (Bleck and Liu 2007; $\mathrm{Xu}$ et al 2012; de Fond et al. 2015) and agency problems caused by management opportunistic behaviors, such as corporate tax avoidance, in-service excess perks for executives (Xu et al. 2014), and over-investment are the two main sources of crash risk. The second aspect is the impact of internal and external corporate governance mechanisms on crash risk, such as ownership structure (Wang et al. 2015), institutional investors' shareholding (Xu et al. 2013) and external auditing (Jiang and Yi 2013; Wan 2015) suppressing or promoting crash risk. Compared with developed countries, the capital market in China is more vulnerable and unstable because of systemic defects, the limited influence of institutional investors, and the strong fluctuation of investor sentiment. Therefore, it is of great significance to study crash risk to maintain the stability of the capital market, protect the interests of investors, and improve corporate governance. Due to the objective existence of agency problems, management has motivation to engage in opportunistic behavior by concealing bad news to obtain personal income, which results in acute crash risk. The provisions of CAMs in the new audit standard may affect crash risk through two potential mechanisms: influencing management decisionmaking and changing the information environment in the capital market.

From the perspective of corporates and management, the disclosure of CAMs may inhibit their opportunistic behavior and reduce crash risk through the following two aspects. On the one hand, rational CPAs may choose to disclose more detailed and accurate risk information in the audit report to avoid additional legal responsibility brought about by the disclosure of key audit matters (which requires CPAs to obtain a high audit quality), such as implementing more effective audit procedures to obtain more sufficient and appropriate audit evidence. Yang et al. (2018) conduct an empirical study using data on China's listed companies, which shows that the disclosure of CAMs could improve audit quality and ultimately suppress earnings management; the result provides direct evidence that the new audit standard improves corporate governance. On the other hand, the disclosure of CAMs can exert "disclosure pressure" on management and directly restrain opportunistic behavior. In the traditional mode of audit reports, management treatment of accounting items and the control and supervision of management by CPAs are in a "black box," resulting in the unavailability of key information to external report users. Management only needs to obtain the approval of CPAs for the adjustment and modification of statements without considering the reaction of investors and the market. Finally, there are limits on the role of the audit report in alleviating agency problems, which greatly reduces the cost of management's concealing negative information and then engaging in opportunistic behavior. While CAMs expose the risk of misstatement and treatment by CPAs to the capital market and investors, management can only act by reducing their opportunistic behavior of preventing the disclosure of controversial information to obtain the recognition of the market and investors. Consequently, crash risk is mitigated by the disclosure pressure exerted on management. 
From the perspective of investors and the information environment, the new audit standard also constitutes a significant mechanism for alleviating information asymmetry and changing the information environment in capital markets; this is due to the information contained in CAMs about the risk of misstatement and how CPAs supervise and control the behavior of management in audited entities (PCAOB (Public Company Accounting Oversight Board) 2017; Tang 2015). Against the background of the severe information asymmetry in the Chinese capital market, management's motivation to voluntarily disclose negative information is relatively low. Therefore, investors may be forced to rely more on reports issued by analysts, the CPAs, and other information intermediaries to obtain negative information on the company. Relevant studies in China argue that CAMs disclosed by CPAs constitute incremental information (Chen and Zhang 2019; Wang et al. 2018; Wang and Wang 2019). According to these conclusions, the disclosure of CAMs can deepen investors' understanding of a specific company, reduce investors' expectations on the company's performance and finally, prevent stock price bubbles by changing the information environment. In addition, due to the bad news released in advance in the form of CAMs, the subsequent downward pressure on the stock price will be released only after the negative incremental information is incorporated into the stock price. Ultimately, crash risk is reduced through another mechanism relevant to the information environment and investors' investment decisions changed by CAMs (Christensen et al. 2014). The logical mind map of the hypothesis development is shown in Fig. 1.

Based on the analysis and deduction above, we propose our hypothesis:

Hypothesis: The disclosure of CAMs has a mitigating effect on stock price crash risk.

\section{Research design}

\section{Sample and data}

The new audit standard was first implemented in 2016, as a transitional year. Per policy, only A + H cross-listing firms were required to disclose CAMs. Because the rest of the listed firms were not included in the transitional year, the regulation divided the firm population conveniently into control and treatment groups. We take advantage of this policy design to construct a DID model to test the impact of the new audit standard on crash risk. Since 2016 was the first year of implementation, the CAMs data and all control variables were taken from the period 2015-2016. Considering that the process through which CAMs influence stock price crash risk may take a certain time,

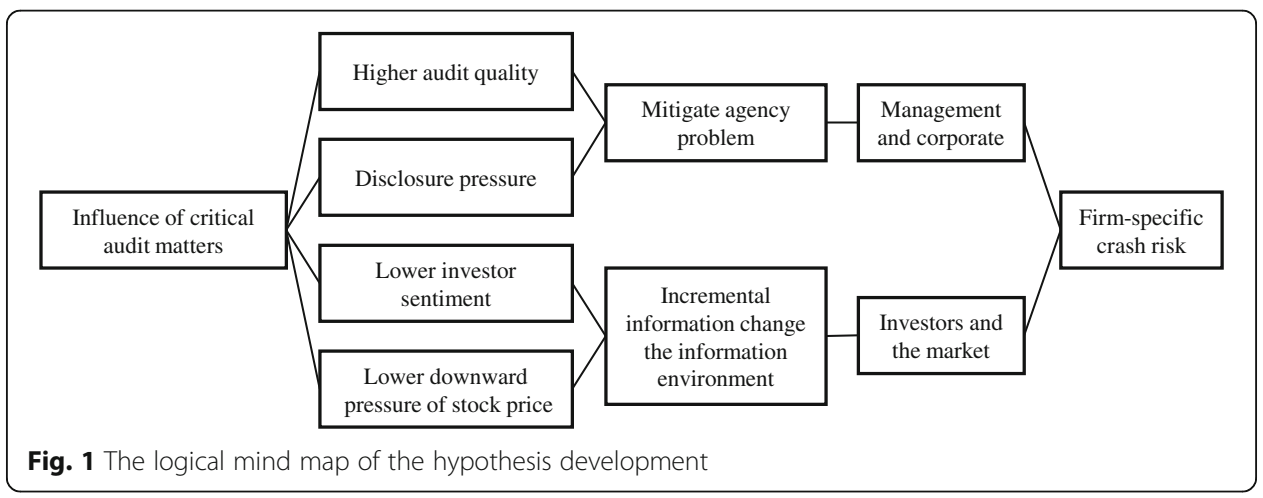


the data on stock price crash risk were taken from the period 2016-2017. After eliminating invalid observations with missing data, we obtained 3964 effective observations.

Having recognized the mechanism of CAMs' influence on crash risk and the entire capital market, we used the number of CAMs in one audit report as a proxy variable for the amount of information in an audit report to explore the issue of incremental information in CAMs. Since the new audit standard was fully implemented in 2017 (a year after the transitional period), we used 2017 data to address this problem. We manually collected the number and category of CAMs in each audit report for all listed companies in 2017 from the official websites of the Shanghai and Shenzhen Stock Exchanges. As mentioned before, considering the time lag, the data on stock price crash risk were taken from 2018. After eliminating invalid observations with missing data, we obtained 2324 effective observations.

In addition, the data on stock prices, stock trading, corporate financial statements, and corporate governance are available from the RESSET and CSMAR databases. We winsorize all continuous variables at the $1 \%$ level in both tails.

\section{Variables settings}

\section{Measuring firm-specific crash risk}

Firm-specific crash risk is the explained variable in this study. Following prior literature (Jiang and Yi 2013; Kim and Zhang 2012; Xu et al. 2013), we use two measures of crash risk to provide robust conclusions. Regardless of which measure is used, however, firm-specific weekly returns of stocks need to be calculated. The method of estimation is as follows. First, we regress weekly returns of each firm against current week market returns and the returns for the 2 weeks before and after in Eq. (1); this is to obtain the residual error $\varepsilon_{i, t}$ as the weekly stock return adjusted by the market return. Second, we define $W_{i, t}=\ln \left(1+\varepsilon_{i, t}\right)$ as firm-specific weekly returns of firm $i$ in year $t$, which is the part of the return that cannot be explained by the market return. Having obtained $W_{i, t}$, we calculate the crash risk for each firm by the two methods mentioned above.

$$
r_{i, t}=\alpha_{i}+\beta_{1} r_{m, t-2}+\beta_{2} r_{m, t-1}+\beta_{3} r_{m, t}+\beta_{4} r_{m, t+1}+\beta_{5} r_{m, t+2}+\varepsilon_{i, t} .
$$

The first measure of firm-specific crash risk is NCSKEW, which is the negative coefficient of skewness of the weekly return after market adjustment. The calculation method is shown in Eq. (2), where $n$ is the number of weeks of stock trading in the year. When the bad news that management intentionally conceals accumulates to a certain extent, the negative coefficient of skewness of the weekly return gets higher, corresponding to greater crash risk.

$$
N \operatorname{CSKE} W_{i, t}=-\left[n(n-1)^{\frac{3}{2}} \sum W_{i, t}^{3}\right] /\left[(n-1)(n-2)\left(\sum W_{i, t}^{2}\right)^{\frac{3}{2}}\right] .
$$

The second measure of firm-specific crash risk is down-to-up volatility (DUVOL). The calculation method is shown in Eq. (3), where $n_{u}$ and $n_{d}$ are the number of up and down weeks respectively, and $R$ is the standard deviation of firm-specific weekly returns of firm $i$ in year $t$. Here, we take the annual mean of stock returns as the standard and then divide the fluctuation of stock prices into a rising stage and a falling stage according to the standard. When the bad news that the company intentionally conceals 
accumulates to a certain level, the decline stage of the stock price is shorter and the volatility is more intense, which makes $R_{d}$ and $D U V O L$ higher, corresponding to a greater crash risk. We use $D U V O L$ to test for robustness.

$$
D U V O L_{i, t}=\ln \left\{\left[\left(n_{u}-1\right) \sum_{\text {down }} R_{d}^{2}\right] /\left[\left(n_{d}-1\right) \sum_{u p} R_{u}^{2}\right]\right\}
$$

\section{CAMs, the number of CAMs, and the category of CAMs}

CAMs and their features (the number and category) are explanatory variables in this study. Following previous research methods on CAMs (Chen and Zhang 2019; Wang et al. 2018; Wang and Wang 2019; Yang et al. 2018), we employ the DID model, where CAM_TREAT is a dummy variable representing observations from the treatment group. Firms that are required to disclose CAMs by the new audit standard in 2016 equal 1, otherwise they equal 0. CAM_YEAR is a dummy variable for the year of policy implementation. Year 2016 equals 1 and year 2015 equals 0. TREAT.YEAR is defined as the interactive term of the two dummy variables above, calculated by multiplying $C A M_{-}$ TREAT by CAM_YEAR. Only when CAM_TREAT and CAM_YEAR equal to 1 at the same time is the value of the interactive term TREAT.YEAR taken as 1. From the perspective of econometrics, this means that differences caused by other unobservable factors between the years before and after the implementation of the new audit standard and between the treatment group and the control group can be eliminated. Consequently, we can clearly and explicitly observe whether the stock price crash risk of the observations from the treatment group changes significantly after the implementation of the new policy; this is how the DID model solves potential endogeneity problems.

Having recognized the mechanism of CAMs' influence on crash risk and the whole capital market, we use the number of CAMs and define DumIdio and NumIdio in one audit report to explore the issue of incremental information in CAMs. The number of CAMs represents the amount of potential incremental information in the audit report; DumIdio is a dummy variable and equals 1 when corporate-idiosyncratic CAMs are contained in one audit report after eliminating industry-homogeneous CAMs (the top four categories by the proportion of the CAMs contained in the audit reports of firms in the same industry); NumIdio is a continuous variable representing the number of corporate-idiosyncratic CAMs. If one audit report contains corporate-idiosyncratic CAMs other than industry-homogeneous CAMs, firm-specific information about risk is released to the capital market, and DumIdio equals 1 , otherwise it equals 0 . The larger NumIdio is, the more corporate-level information related to one specific firm is contained in the audit report. In section 4.4, we introduce the train of thought on how to use these variables to discuss the issue of incremental information in CAMs in detail.

\section{Control variables}

Using previous scholars' research achievements about crash risk as a reference (Jiang and Yi 2013; Kim and Zhang 2012; Wang et al. 2015; Xu et al. 2013), we define firm size, firm transparency, ROA, leverage, change of turnover rate, standard deviation of firm-specific weekly return rate, book-to-market ratio, nature of property right, stock share of the largest shareholder, and proportion of independent directors in the board 
of directors as control variables which may have an influence on crash risk. We also control for industry fixed effects in the regression. Table 1 illustrates the details and calculation methods for each variable.

\section{Model settings}

To test for the hypothesis, we use the data from 2015 and 2016-one year before and after the policy was implemented-to establish the following DID model:

$$
\begin{aligned}
\text { Crash }_{t}= & \alpha_{0}+\alpha_{1} \text { CAM_TREAT }_{t-1}+\alpha_{2} \text { CAM_Y YEAR }_{t-1}+\alpha_{3} \text { TREAT YEAR }_{t-1} \\
& + \text { ACONTROLS }_{t-1}+\text { IND. }
\end{aligned}
$$

The coefficient to be tested is $\alpha_{3}$-the coefficient of the interactive term TREA $T \cdot Y E A R$. If $\alpha_{3}$ is significantly negative, then the hypothesis will be supported.

When all listed companies were required to disclose CAMs for the first year, the number and category of CAMs are manually collated from 2017. The regression model is established for testing the impact of the number and category of CAMs as follows:

$$
\text { Crash }_{t}=\beta_{0}+\beta_{1} \text { NumCAM }_{t-1}+\text { BControls }_{t-1}+\text { IND. }
$$

\begin{tabular}{|c|c|c|}
\hline Variable & Symbol & Details and calculation methods \\
\hline \multirow[t]{2}{*}{$\begin{array}{l}\text { Explained } \\
\text { variable }\end{array}$} & NCSKEW & $\begin{array}{l}\text { Negative coefficient of skewness of firm-specific weekly returns, see Eq. (2) for es- } \\
\text { timation method }\end{array}$ \\
\hline & DUVOL & $\begin{array}{l}\text { Down-to-up volatility of firm-specific weekly returns, see Eq.(3) for estimation } \\
\text { method }\end{array}$ \\
\hline \multirow{4}{*}{$\begin{array}{l}\text { Explanatory } \\
\text { variable }\end{array}$} & TREAT.YEAR & The interactive term in the DID model \\
\hline & NumCAM & The number of CAMs in one audit report \\
\hline & Dumldio & $\begin{array}{l}\text { Dummy variable, whether corporate-idiosyncratic CAMs are contained in one } \\
\text { audit report }\end{array}$ \\
\hline & Numldio & The number of corporate-idiosyncratic CAMs in one audit report \\
\hline \multirow{11}{*}{$\begin{array}{l}\text { Control } \\
\text { variable }\end{array}$} & Size & Firm size, the natural log of a firm's total assets \\
\hline & ABS_DA & $\begin{array}{l}\text { Firm transparency, the absolute value of discretionary accruals calculated by the } \\
\text { modified Jones model }\end{array}$ \\
\hline & $R O A$ & $\begin{array}{l}\text { Return on total assets, calculated as income before extraordinary items divided } \\
\text { by total assets }\end{array}$ \\
\hline & Lev & Firm financial leverage, calculated as total liabilities divided by total assets \\
\hline & Dturn & $\begin{array}{l}\text { Change of annual turnover rate, calculated as the difference between the annual } \\
\text { turnover rate for this year and last year divided by the annual turnover rate for } \\
\text { last year }\end{array}$ \\
\hline & StdW & Standard deviation of firm-specific weekly return rates \\
\hline & $M B$ & book-to-market ratio \\
\hline & $S O E$ & $\begin{array}{l}\text { Dummy variable, the nature of property right, equals } 1 \text { if ultimate controlling } \\
\text { owner is the country }\end{array}$ \\
\hline & Top 1 & Stock share of the largest shareholder \\
\hline & Independent & The proportion of independent directors in the board of directors \\
\hline & IND & Industry fixed effect \\
\hline
\end{tabular}

The coefficient of interest is $\beta_{1}$, which is expected to be significantly negative.

Table 1 Details and calculation methods of variables 


\section{Empirical results \\ Descriptive statistics}

Table 2 displays the summary statistics of the relevant variables. In terms of crash risk, the average of $N C S K E W_{t}$ and $D U V O L_{t}$ are -0.543 and -0.400 , respectively, while the standard deviations are 1.371 and 1.003, respectively. The average size of sample is 22.25; state-owned firms account for $39.5 \%$ of the total; the average proportion of the largest shareholder is $35.33 \%$, indicating that the phenomenon of "high ownership concentration with dominating shareholder" prevails in listed firms in China. Overall, there is no significant difference in the descriptive statistics between previous studies and ours.

\section{CAM and firm-specific crash risk}

The fundamental regression results of CAMs and crash risk are presented in Table 3. Columns (1) and (2) take NCSKEW $W_{t}$ as an explanatory variable. Column (2) reports the regression results of Eq. (4) while Column (1) excludes the control variables in Eq. (4). The results show that the coefficients of the interactive term TREAT.YEAR are significantly negative, which indicates that, with the implementation of the new audit standard, crash risk is significantly mitigate. This effect is relatively pure, as it is relatively less affected by the choice of control variables. These results offer preliminary support for our hypothesis. In terms of the control variables, $S i z e_{t-1}, S O E_{t-1}$, and $S t d W_{t-1}$ are significantly positively correlated with crash risk, which indicates that factors such as expansion of company size, being state-owned, and an increase in fluctuation in stock returns will significantly increase firm-specific crash risk. This is generally consistent with conclusions in previous research (Kim and Zhang 2012; Ye et al. 2015) and is in line with our economic intuition.

Table 2 Summary statistics of variables

\begin{tabular}{llllll}
\hline & $\mathbf{( 1 )}$ & $\mathbf{( 2 )}$ & $\mathbf{( 3 )}$ & $\mathbf{( 4 )}$ & $\mathbf{( 5 )}$ \\
Variable & No. of obs. & Mean & Std. dev. & Min & Max \\
\hline NCSKEW $_{t}$ & 3964 & -0.543 & 1.371 & -3.827 & 3.022 \\
DUVOL $_{t}$ & 3964 & -0.400 & 1.003 & -2.795 & 2.330 \\
CAM_TREAT $_{t-1}$ & 3964 & 0.0356 & 0.185 & 0 & 1 \\
CAM_YEAR & 3964 & 0.517 & 0.500 & 0 & 1 \\
TREAT.YEAR $_{t-1}$ & 3964 & 0.0187 & 0.136 & 0 & 1 \\
Size $_{t-1}$ & 3964 & 22.25 & 1.350 & 19.64 & 27.04 \\
ABS_DA $_{t-1}$ & 3964 & 0.0665 & 0.0704 & 0.000740 & 0.415 \\
ROA $_{t-1}$ & 3964 & 0.0323 & 0.0530 & -0.183 & 0.183 \\
LeV $_{t-1}$ & 3964 & 0.449 & 0.217 & 0.0521 & 0.937 \\
Dturn $_{t-1}$ & 3964 & 0.689 & 0.839 & -0.545 & 3.815 \\
StdW $_{t-1}$ & 3964 & 0.0609 & 0.0231 & 0.0234 & 0.134 \\
MB $_{t-1}$ & 3964 & 2.677 & 1.980 & 0.983 & 13.37 \\
SOE $_{t-1}$ & 3964 & 0.395 & 0.489 & 0 & 1 \\
Top1 $_{t-1}$ & 3964 & 35.33 & 14.84 & 9.490 & 74.82 \\
Independent $_{t-1}$ & 3964 & 0.374 & 0.0528 & 0.308 & 0.571 \\
\hline & & & & &
\end{tabular}


Table 3 CAMs and stock price crash risk

\begin{tabular}{|c|c|c|c|c|}
\hline & $\begin{array}{l}\text { (1) } \\
\text { Full sample }\end{array}$ & $\begin{array}{l}\text { (2) } \\
\text { Full sample }\end{array}$ & $\begin{array}{l}\text { (3) } \\
\text { PSM 1:1 }\end{array}$ & $\begin{array}{l}\text { (4) } \\
\text { PSM 1:2 }\end{array}$ \\
\hline Variable & NCSKEW & NCSKEW & NCSKEW & NCSKEW \\
\hline \multirow[t]{2}{*}{$\overline{C A M}{ }_{1} T_{R E A T} T_{t-1}$} & 0.125 & -0.0622 & $0.685^{b}$ & 0.326 \\
\hline & $(0.159)$ & $(0.168)$ & $(0.314)$ & $(0.240)$ \\
\hline \multirow[t]{2}{*}{$C A M_{-} Y E A R_{t-1}$} & $0.149^{c}$ & $-0.107^{\mathrm{a}}$ & 0.0543 & 0.119 \\
\hline & (0.0399) & $(0.0568)$ & $(0.362)$ & $(0.247)$ \\
\hline \multirow[t]{2}{*}{ TREAT.YEAR ${ }_{t-1}$} & $-0.458^{a}$ & $-0.403^{\mathrm{a}}$ & $-0.725^{a}$ & $-0.534^{a}$ \\
\hline & $(0.235)$ & $(0.236)$ & $(0.428)$ & $(0.318)$ \\
\hline \multirow[t]{2}{*}{ Size $_{t-1}$} & & $0.113^{c}$ & 0.159 & 0.0127 \\
\hline & & $(0.0276)$ & $(0.124)$ & $(0.0901)$ \\
\hline \multirow[t]{2}{*}{$A B S_{-} D A_{t-1}$} & & 0.248 & $-3.507^{b}$ & $-2.451^{\mathrm{a}}$ \\
\hline & & $(0.327)$ & (1.698) & (1.413) \\
\hline \multirow[t]{2}{*}{$R O A_{t-1}$} & & 0.226 & -4.992 & -3.407 \\
\hline & & $(0.486)$ & (3.379) & $(2.664)$ \\
\hline \multirow[t]{2}{*}{$\operatorname{LeV}_{t-1}$} & & -0.160 & 0.178 & -0.734 \\
\hline & & $(0.143)$ & $(0.926)$ & $(0.684)$ \\
\hline \multirow[t]{2}{*}{ Dturn $_{t-1}$} & & 0.00362 & 0.0440 & -0.0274 \\
\hline & & $(0.0297)$ & (0.138) & $(0.0559)$ \\
\hline \multirow[t]{2}{*}{$S t d W_{t-1}$} & & $5.048^{c}$ & 0.787 & -1.923 \\
\hline & & $(1.215)$ & $(6.701)$ & $(5.136)$ \\
\hline \multirow[t]{2}{*}{$M B_{t-1}$} & & $0.0532^{c}$ & $0.625^{a}$ & -0.120 \\
\hline & & $(0.0145)$ & $(0.368)$ & $(0.240)$ \\
\hline \multirow[t]{2}{*}{$S O E_{t-1}$} & & $0.133^{c}$ & -0.148 & -0.105 \\
\hline & & $(0.0502)$ & $(0.287)$ & $(0.234)$ \\
\hline \multirow[t]{2}{*}{$\operatorname{Top}_{t-1}$} & & -0.00256 & -0.000638 & -0.00167 \\
\hline & & $(0.00156)$ & $(0.00790)$ & $(0.00616)$ \\
\hline \multirow[t]{2}{*}{ Independent $t_{t-1}$} & & 0.317 & $-3.196^{\mathrm{a}}$ & $-3.069^{b}$ \\
\hline & & $(0.412)$ & $(1.841)$ & $(1.514)$ \\
\hline \multirow[t]{2}{*}{ Constant } & & $-3.515^{c}$ & -3.890 & 1.473 \\
\hline & & $(0.622)$ & (3.205) & $(2.177)$ \\
\hline IND & No & Yes & Yes & Yes \\
\hline No. of obs. & 4832 & 3964 & 179 & 285 \\
\hline
\end{tabular}

Notes. ${ }^{\mathrm{a}},{ }^{\mathrm{b}}$ and ${ }^{\mathrm{c}}$ represent the significance levels of $10 \%, 5 \%$, and $1 \%$, respectively

There is one tricky problem of self-selection in our sample, owing to the fact that the grouping process was not completely random, as the treatment group consists entirely of $\mathrm{A}+\mathrm{H}$ cross-listed firms. Self-selection may lead to misleading results because other unobservable characteristics that are common among $\mathrm{A}+\mathrm{H}$ cross-listed firms can explain the results too. To eliminate the bad effects of self-selection and to achieve as random an experiment as possible, we apply the propensity score matching method (PSM) to ensure the reliability of our conclusion.

Column (3) and Column (4) in Table 3 present the regression results of 1:1 and 1:2 nearest neighbor matching, with 179 and 285 observations in the recombined samples, respectively. Except that the sample has been selected, the other treatments are the same as in Column (2). The results in Columns (3) and (4) still show that the disclosure 
of CAMs can significantly reduce crash risk. This strengthens the reliability of our research, provides more robustness, and further supports the hypothesis.

The fundamental test provides further evidence for previous discussions on whether CAMs can have a significant impact on the Chinese capital market (Chen and Zhang 2019; Wang et al. 2018; Wang and Wang 2019).

\section{The mechanism of CAMs influencing crash risk}

According to the definition of stock price crash risk, a crash arises from an accumulation of bad news. Yang et al. (2018) find that the disclosure of CAMs reduced earnings management by improving audit quality; this suggests that the new audit standard will suppress opportunistic behavior of management by improving audit quality and exerting disclosure pressure, ultimately reducing crash risk at the source. Apart from this observation, however, the impact of CAMs on crash risk can be explained from the perspective of the information environment and investors, which may be another reasonable mechanism to explain the phenomenon. More concretely, the incremental information contained in CAMs released to the capital market constitutes negative messages that change the information environment and investment decisions and reduce investor sentiment, reducing stock price bubbles. Additionally, the negative information in CAMs is released to the capital market in advance, which relieves the downward pressure on subsequent stock prices, thus curbing crash risk. The crucial part of the logical chain of this new mechanism is that the incremental information contained in CAMs is a negative message to investors and the market. Conversely, if CAMs are positive information, the stock price may be further inflated, driven by a higher sentiment of investors and the market, intensifying the downward pressure on stock prices, and eventually leading to a more severe crash.

The global reform wave of audit standards inherited the essence of releasing material misstatement risks that was first proposed in the United Kingdom, and therefore CAMs may essentially include the misstatement risks of the financial statements of firms (Tang et al. 2015), which indicate other potential risks associated with operating, financing, strategy, etc. It is the disclosure of risks of misstatement to the public through CAMs that constitutes the core idea of the new audit standard to reduce information asymmetry. Therefore, from the perspective of the standard itself, CAMs are associated with negative information. However, Wang et al. (2018) find that, after the implementation of the new audit standard, the cumulative abnormal returns of stocks in the window period of the disclosure day of the annual report were significantly higher than before; this result, which seems to run counter to market reaction to bad news under the assumption of a perfect capital market, provides evidence that CAMs may bear positive information. Therefore, regarding the issue of whether the information contained in CAMs constitutes negative or positive information, there is no specific research with a definitive conclusion.

To address this issue, we introduce the opposite of crash risk-positive jump of stock price. Referring to Hutton et al. (2009), we use Eq. (6) to estimate whether there is a positive jump of stock price:

$$
W_{i, t} \geq \text { Average }\left(W_{i, t}\right)+3.09 \sigma_{i},
$$

where $W_{i, t}$ is the firm-specific weekly return of firm $i$ in year $t$ obtained from Eq. (1), 
Average $\left(W_{i, t}\right)$ is the average firm-specific weekly return, and $\sigma_{i}$ is the standard deviation of firm-specific weekly returns of firm $i$ in an accounting year. We define positive jump as a dummy variable. If the firm-specific weekly return of firm $i$ satisfies Eq. (6) one or more times in one accounting year, the variable "Jump" equals 1, which indicates that the stock price rose extremely in that year; otherwise the variable equals 0 .

Given that management also has motivation to conceal positive news and that the nature of CAMs is at least neutral, we should observe CAMs' depressing effect on a stock price if management chooses to conceal any information due to self-interest; this is because the disclosure of CAMs can also reduce upward pressure on stock prices through positive incremental information. However, firms and managers usually have no incentive to conceal good news (Hutton et al. 2009); it is inappropriate to obtain sufficient evidence simply by using a whole sample in addressing this problem. When executives are awarded equity incentives, they may have a motivation to suppress an upward trend in stock price by concealing good news, to lower the grant price for subsequent profit. Therefore, we reselect a sub-sample consisting of firms that implemented an equity incentive plan from 2013 to 2015, to establish a situation in which management is motivated to conceal good news. We then examine the inhibitory effect of CAMs on positive jump and establish the nature of CAMs. If CAMs constitute negative information, we expect to observe an inhibitory effect of CAMs on stock price positive jump for a firm implementing an equity incentive plan, that is, the effect of CAMs on crash risk and positive jump is asymmetric given a motivation to conceal bad news and good news.

Table 4 reports the results of the analysis above, in which the explained variable is Jump. Columns (1) and (2) present the results of the Probit and Logit models for the whole sample, respectively. Although the coefficient of the interactive term is negative, it is not significant statistically. Columns (3) and (4) show the results of the Probit and Logit models, respectively, for the subsample of firms implementing an equity incentive plan from 2013 to 2015. The results show that the coefficients of the interactive term remain insignificant statistically, indicating that the implementation of the new audit standard cannot significantly suppress positive jump even if executives have a motivation to conceal good news. The result provides indirect evidence that the information contained in CAMs is negative. Besides CAMs strengthening the role of audit as an external mechanism for corporate governance, it is further shown that CAMs containing negative information reduces investor sentiment and alters investor decisions by changing the information environment of the capital market. The mechanism thus prevents price bubbles, releases downward pressure and finally mitigates crash risk.

\section{Further discussion: look for CAMs that contain incremental information}

In Section 4.3, we demonstrate the mechanism of CAMs' impact on firm-specific crash risk through a special research design. Through the earlier release of negative news, CAMs can ease downward pressure on stock prices to achieve the suppression of crash risk by market mechanism. In this section, we continue to discuss the issue of incremental information in CAMs. However, we cannot be certain that all CAMs contain incremental information. We emphasize, before our next empirical test, that CAMs are merely potentially informative. Therefore, the speculation that the more CAMs there 
Table 4 CAMs and stock price positive jump

\begin{tabular}{|c|c|c|c|c|}
\hline Variable & $\begin{array}{l}\text { (1) Probit } \\
\text { Full sample } \\
\text { Jump }\end{array}$ & $\begin{array}{l}\text { (2) Logit } \\
\text { Full sample } \\
\text { Jump }\end{array}$ & $\begin{array}{l}\text { (3) Probit } \\
\text { Subsample } \\
\text { Jump }\end{array}$ & $\begin{array}{l}\text { (4) Logit } \\
\text { Subsample } \\
\text { Jump }\end{array}$ \\
\hline \multirow[t]{2}{*}{$\overline{C A M}{ }_{-} T R E A T_{t-1}$} & $0.322^{\mathrm{a}}$ & $0.630^{\mathrm{a}}$ & 0.685 & 1.346 \\
\hline & $(0.183)$ & $(0.329)$ & $(0.598)$ & $(0.985)$ \\
\hline \multirow[t]{2}{*}{$C A M_{-} Y E A R_{t-1}$} & $0.610^{c}$ & $1.149^{c}$ & $0.672^{c}$ & $1.265^{c}$ \\
\hline & $(0.0700)$ & $(0.134)$ & $(0.186)$ & $(0.356)$ \\
\hline \multirow[t]{2}{*}{ TREAT.YEAR ${ }_{t-1}$} & -0.0933 & -0.268 & -1.236 & -2.227 \\
\hline & $(0.240)$ & $(0.413)$ & $(0.872)$ & $(1.497)$ \\
\hline \multirow[t]{2}{*}{$\operatorname{Size}_{t-1}$} & $0.120^{c}$ & $0.218^{c}$ & $0.248^{c}$ & $0.411^{b}$ \\
\hline & $(0.0332)$ & $(0.0612)$ & $(0.0961)$ & $(0.173)$ \\
\hline \multirow[t]{2}{*}{$A B S \_D A_{t-1}$} & $-0.899^{b}$ & $-1.484^{\mathrm{a}}$ & -1.079 & -1.822 \\
\hline & $(0.426)$ & $(0.797)$ & $(1.140)$ & $(2.110)$ \\
\hline \multirow[t]{2}{*}{$R O A_{t-1}$} & 0.969 & 1.643 & 1.290 & 1.837 \\
\hline & $(0.603)$ & $(1.126)$ & (1.798) & $(3.237)$ \\
\hline \multirow[t]{2}{*}{$\operatorname{LeV}_{t-1}$} & -0.257 & -0.471 & -0.529 & -1.003 \\
\hline & $(0.179)$ & $(0.333)$ & $(0.557)$ & $(1.029)$ \\
\hline \multirow[t]{2}{*}{ Dturn $_{t-1}$} & $0.0791^{b}$ & $0.140^{b}$ & -0.109 & -0.174 \\
\hline & $(0.0345)$ & $(0.0622)$ & $(0.112)$ & $(0.206)$ \\
\hline \multirow[t]{2}{*}{$S t d W_{t-1}$} & -1.384 & -2.454 & -2.903 & -5.363 \\
\hline & $(1.424)$ & $(2.607)$ & (3.519) & $(6.461)$ \\
\hline \multirow[t]{2}{*}{$M B_{t-1}$} & $0.0437^{b}$ & $0.0823^{c}$ & $0.131^{c}$ & $0.238^{c}$ \\
\hline & $(0.0174)$ & $(0.0315)$ & $(0.0460)$ & $(0.0825)$ \\
\hline \multirow[t]{2}{*}{$S O E_{t-1}$} & 0.0607 & 0.104 & $0.556^{\mathrm{b}}$ & $0.970^{\mathrm{b}}$ \\
\hline & $(0.0616)$ & $(0.114)$ & $(0.222)$ & $(0.386)$ \\
\hline \multirow[t]{2}{*}{ Top $1_{t-1}$} & 0.000107 & 0.000254 & 0.00245 & 0.00607 \\
\hline & $(0.00189)$ & $(0.00352)$ & $(0.00513)$ & $(0.00973)$ \\
\hline \multirow[t]{2}{*}{ Independent $t_{t-1}$} & -0.590 & -1.001 & -0.615 & -1.309 \\
\hline & $(0.510)$ & $(0.945)$ & $(1.117)$ & $(2.103)$ \\
\hline \multirow[t]{2}{*}{ Constant } & $-4.165^{c}$ & $-7.457^{c}$ & $-6.728^{c}$ & $-11.31^{c}$ \\
\hline & $(0.752)$ & (1.398) & $(2.191)$ & (3.943) \\
\hline IND & Yes & Yes & Yes & Yes \\
\hline No. of obs. & 3964 & 3964 & 691 & 691 \\
\hline
\end{tabular}

Notes. ${ }^{\mathrm{a}},{ }^{\mathrm{b}}$ and ${ }^{\mathrm{c}}$ represent the significance levels of $10 \%, 5 \%$, and $1 \%$, respectively

are in one audit report, the more information is released to the market, which means that every CAM contains incremental information, may not be true. At the beginning of the implementation (of the new standard), some policymakers and scholars had doubts and suspected that CAMs might eventually become cliché and useless platitudes (Tang 2015); this indicates that not all CAMs contain the same amount of information, due to various reasons. When we observe and summarize CAMs in the audit reports of listed companies in China in recent years, we find many matters with highly homogeneous content and expression, especially among companies in the same industry. These companies are highly similar in nature and, consequently, the operating and business risks are also similar to a great extent, which eventually leads to the same risk of misstatement. Therefore, disclosing too many CAMs that do not contain firm-specific 
incremental information may not reflect the core philosophy of the new audit standard. In addition, the disclosure of CAMs can reduce potential legal liability for CPAs (Kachelmeier et al. 2014). Therefore, in the event that material misstatement risk might exist, rational CPAs may choose to disclose more CAMs that contain industrycommon operating and financing risks in audit reports, to reduce the potential legal liability or merely to meet the formal regulatory requirements; this may also lead to an absence of firm-specific information in CAMs. Considering the two factors above, the question of whether all CAMs have incremental information remains to be verified.

Column (1) in Table 6 uses Eq. (5) and presents the results on the relationship between the number of CAMs in one audit report and crash risk. We use the sample of 2017 because this is the first year that the new audit standard gets fully implemented, and the data on crash risk are from 2018, due to the time-lag issue. The results show that the increase in the number of CAMs cannot significantly mitigate crash risk. This result is not surprising, given the analysis above, which indicates that not all CAMs contain incremental information.

Despite all this, we cannot take the view that all CAMs do not contain incremental information at all, because we have shown that CAMs can suppress stock price crash risk through market mechanism in the main test and the mechanism test. Therefore, the focus of our following discussion is to find CAMs that contain firm-specific incremental information. Specifically, according to the industry classification standard of China Securities Regulatory Commission (CSRC), we use the data from 2017 and calculate the proportion of all categories of CAMs that are disclosed of all firms in the same industry. We then rank different categories of CAMs from high to low, according to the proportion mentioned above, and gradually eliminate the category of CAMs with the highest proportion from each observation. The regression results gradually approach the significance level with progressive elimination, and the significance remains until the top four categories of CAMs are eliminated, as shown in Fig. 2. Therefore, we define the top four categories of CAMs in one industry as "industry-homogeneous CAMs." Generally speaking, "industry-homogeneous CAMs" in different industries mainly include "recognition of revenue," "dead account preparation rate of accounts

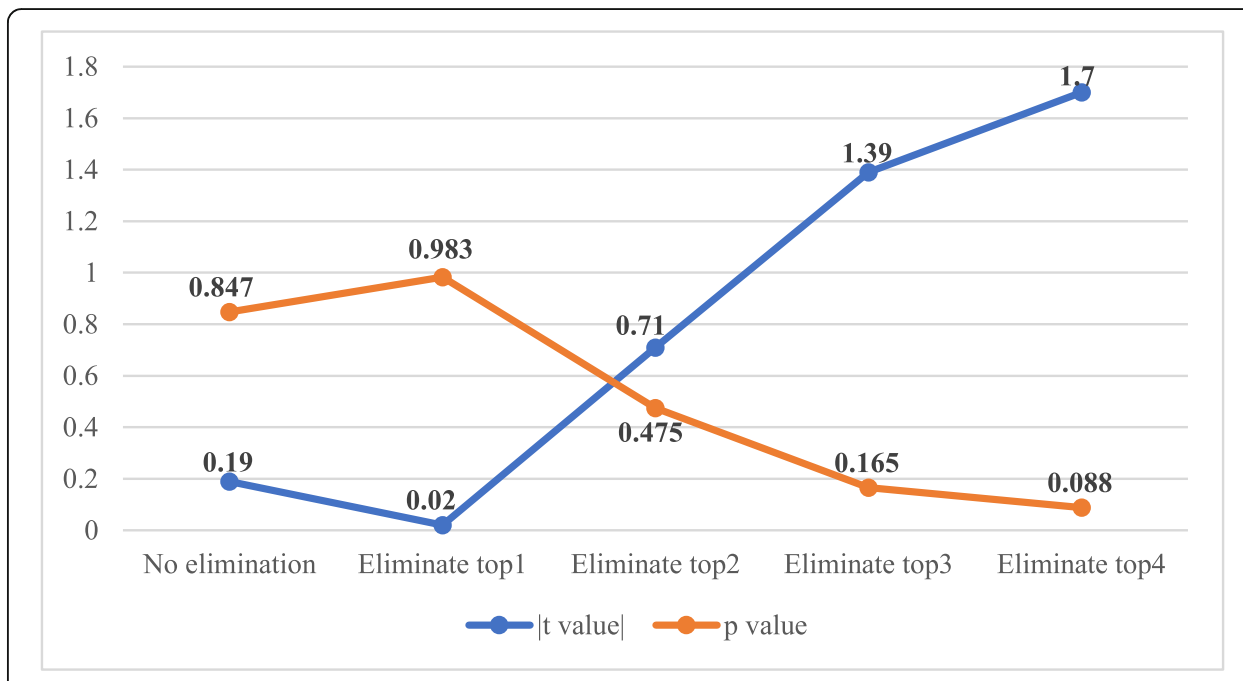

Fig. 2 The trend of significance of regression results of Eq. (5) with the process of elimination 
receivable," "devaluation of goodwill," "devaluation and depreciation of illiquid assets," and "inventory depreciation reserves." Table 5 demonstrates industry-homogeneous CAMs for each industry. After removing these CAMs from our observations, the remaining CAMs are corporate-idiosyncratic CAMs, which mainly include "material assets reorganization," "accounting estimation," "financial instruments," "capitalization," and "government subsidies." After the treatment above, 39.3\% of the firms of the whole sample disclose at least one corporate-idiosyncratic CAM, and the average number of CAMs in one audit report is 0.48 , which is about $77 \%$ lower than that of 2.11 before the treatment.

Columns (2) and (3) of Table 6 report the results after eliminating industryhomogeneous CAMs with the same settings as in Eq. (5). Column (2) takes DumIdio $_{t-1}$ "whether corporate-idiosyncratic CAM is contained in one audit report" as the explanatory variable, and Column (3) takes NumIdio $o_{t-1}$ "the number of corporate-idiosyncratic CAMs in one audit report" as the explanatory variable. The results show that the disclosure of corporate-idiosyncratic CAMs and increasing the number of corporate-idiosyncratic CAMs in audit reports can significantly mitigate crash risk, with the absolute value of the coefficient of the two explanatory variables significantly increasing compared with Column (1). This means that CAMs with firm-specific information contain incremental information which plays the critical role of information communication, while CAMs with industryhomogeneous information do not contain incremental information to investors and the market. It is the disclosure of corporate-idiosyncratic CAMs in audit reports that releases incremental information on unique risks related to specific firms, changes the information environment, alleviates the information asymmetry between firms and investors and ultimately mitigates crash risk.

\section{CAMs, shareholding of institutional investors, and crash risk}

Our study expands the discussion on whether CAMs are a composition of incremental information in audit reports in China (Chen and Zhang 2019; Wang et al. 2018; Wang and Wang 2019). We contend that CAMs constitute negative incremental information. Moreover, we show that the mechanism holds that negative incremental information in CAMs can mitigate crash risk by changing the information environment, alleviating information asymmetry, and finally by influencing investor sentiment and investment decisions. Since investors and the market are influenced by the information in CAMs, we consider the issue of whether this mechanism may be affected by different types of investors, because different investors may have different reactions to this negative incremental information.

According to the theory of investors' limited attention, investors' attention in an environment with a high concentration of information is limited by a finite information processing and cognitive ability, resulting in the efficiency of investors' information processing decreasing (Egeth and Kahneman 1975). Compared with institutional investors, it may be more difficult for individuals to understand professional expression in audit reports (Asare and Wright 2012). The negative incremental information in CAMs is released through professional auditing expression, which may pose difficulty for individuals in collecting, processing, and utilizing the information efficiently and correctly; 
Table 5 Industry-homogeneous CAMs of different industries in 2017

\begin{tabular}{|c|c|c|c|}
\hline Industry & $\begin{array}{l}\text { Industry-homogeneous } \\
\text { CAMs }\end{array}$ & Industry & $\begin{array}{l}\text { Industry-homogeneous } \\
\text { CAMs }\end{array}$ \\
\hline $\begin{array}{l}\text { Agriculture, forestry, } \\
\text { husbandry and fishery }\end{array}$ & $\begin{array}{l}\text { (1)Recognition of revenue } \\
\text { (2)Inventory depreciation } \\
\text { reserves } \\
\text { (3)Devaluation and } \\
\text { depreciation of illiquid } \\
\text { assets } \\
\text { (4)Devaluation of goodwill }\end{array}$ & Finance & $\begin{array}{l}\text { (1)Financial instruments } \\
\text { (2) Assessment on } \\
\text { consolidating variable } \\
\text { interest entities } \\
\text { (3)Devaluation and } \\
\text { derecognition of loan } \\
\text { (4) Accounting estimation }\end{array}$ \\
\hline Mining & $\begin{array}{l}\text { (1) Recognition of revenue } \\
\text { (2) Devaluation and } \\
\text { depreciation of illiquid } \\
\text { assets } \\
\text { (3)Bad debt reserves of } \\
\text { accounts receivable and } \\
\text { long-term receivables } \\
\text { (4)Devaluation of goodwill }\end{array}$ & Real estate & $\begin{array}{l}\text { (1) Recognition of revenue } \\
\text { (2) Inventory depreciation } \\
\text { reserves } \\
\text { (3) Accounting estimation } \\
\text { (4) Land-value increment } \\
\text { tax }\end{array}$ \\
\hline Manufacturing & $\begin{array}{l}\text { (1) Recognition of revenue } \\
\text { (2) Bad debt reserves of } \\
\text { accounts receivable and } \\
\text { long-term receivables } \\
\text { (3)Devaluation of goodwill } \\
\text { (4) Inventory depreciation } \\
\text { reserves }\end{array}$ & $\begin{array}{l}\text { Leasing and business } \\
\text { services }\end{array}$ & $\begin{array}{l}\text { (1) Recognition of revenue } \\
\text { (2) Bad debt reserves of } \\
\text { accounts receivable and } \\
\text { long-term receivables } \\
\text { (3) Devaluation of goodwill } \\
\text { (4) Assets reorganization }\end{array}$ \\
\hline $\begin{array}{l}\text { Production and supply of } \\
\text { electricity, heat, gas and } \\
\text { water }\end{array}$ & $\begin{array}{l}\text { (1)Recognition of revenue } \\
\text { (2)Devaluation and } \\
\text { depreciation of illiquid } \\
\text { assets } \\
\text { (3)Devaluation of goodwill } \\
\text { (4)Bad debt reserves of } \\
\text { accounts receivable and } \\
\text { long-term receivables }\end{array}$ & $\begin{array}{l}\text { Scientific research and } \\
\text { technology services }\end{array}$ & $\begin{array}{l}\text { (1)Recognition of revenue } \\
\text { (2) Bad debt reserves of } \\
\text { accounts receivable and } \\
\text { long-term receivables } \\
\text { (3) Devaluation of goodwill } \\
\text { (4)Inventory depreciation } \\
\text { reserves }\end{array}$ \\
\hline Construction & $\begin{array}{l}\text { (1) Recognition of revenue } \\
\text { (2) Bad debt reserves of } \\
\text { accounts receivable and } \\
\text { long-term receivables } \\
\text { (3)Devaluation of goodwill } \\
\text { (4) Inventory depreciation } \\
\text { reserves }\end{array}$ & $\begin{array}{l}\text { Water conservancy, } \\
\text { environment and public } \\
\text { facilities management }\end{array}$ & $\begin{array}{l}\text { (1) Recognition of revenue } \\
\text { (2) Bad debt reserves of } \\
\text { accounts receivable and } \\
\text { long-term receivables } \\
\text { (3)Devaluation of goodwill } \\
\text { (4)Devaluation and } \\
\text { depreciation of illiquid } \\
\text { assets }\end{array}$ \\
\hline Wholesale and retail & $\begin{array}{l}\text { (1) Recognition of revenue } \\
\text { (2) Bad debt reserves of } \\
\text { accounts receivable and } \\
\text { long-term receivables } \\
\text { (3)Devaluation of goodwill } \\
\text { (4)Inventory depreciation } \\
\text { reserves }\end{array}$ & Education & $\begin{array}{l}\text { (1) Recognition of revenue } \\
\text { (2) Devaluation of goodwill } \\
\text { (3) Financial instruments }\end{array}$ \\
\hline $\begin{array}{l}\text { Transportation, storage and } \\
\text { postal services }\end{array}$ & $\begin{array}{l}\text { (1) Recognition of revenue } \\
\text { (2) Bad debt reserves of } \\
\text { accounts receivable and } \\
\text { long-term receivables } \\
\text { (3) Devaluation and }\end{array}$ & Health and social work & $\begin{array}{l}\text { (1)Devaluation of goodwill } \\
\text { (2) Recognition of revenue } \\
\text { (3) Financial instruments } \\
\text { (4) Inventory depreciation } \\
\text { reserves }\end{array}$ \\
\hline
\end{tabular}

assets

(4)Devaluation of goodwill

Accommodation and catering

(1) Recognition of revenue (2)Devaluation of goodwill (3) Assets reorganization

(4)Devaluation and depreciation of illiquid assets

Information transmission, software and information technology services
(1) Recognition of revenue

(2) Devaluation of goodwill

(3) Bad debt reserves of

accounts receivable and
Culture, sports and entertainment

.

\section{Others}

Il

\section{ogeneous}

(1)Financial instruments

(s dating variable derecognition of loan (4)Accounting estimation

ORecognition of revenue reserves

Land-value increment

.


Table 5 Industry-homogeneous CAMs of different industries in 2017 (Continued)

\begin{tabular}{lll}
\hline Industry & $\begin{array}{l}\text { Industry-homogeneous } \\
\text { CAMs }\end{array}$ & $\begin{array}{l}\text { Industry } \\
\text { CAMs }\end{array}$ \\
\hline & long-term receivables & long-term receivables \\
& (4) Assets reorganization & \\
\hline
\end{tabular}

the individual investors may even ignore or misunderstand the negative incremental information in CAMs. Sophisticated institutional investors may be less attention-limited and are more likely to interpret the incremental information in CAMs effectively (given their professional ability) and incorporate it into stock prices. Therefore, we predict that the effect of CAMs on crash risk mainly manifests in companies with a high proportion of institutional investors in their shareholders. Table 7 reports the results of

Table 6 The number and category of CAMs and crash risk

\begin{tabular}{|c|c|c|c|}
\hline \multirow[b]{3}{*}{ Variable } & \multirow{3}{*}{$\begin{array}{l}\text { (1) } \\
\text { CAMs } \\
\text { NCSKEW }\end{array}$} & $(2)$ & \multirow[t]{2}{*}{ (3) } \\
\hline & & Corporate-idiosyncratic CAMs & \\
\hline & & NCSKEW & NCSKEW \\
\hline \multirow[t]{2}{*}{ NumCAM } & -0.00304 & & \\
\hline & $(0.0410)$ & & \\
\hline \multirow[t]{2}{*}{ Dumldio $_{t-1}$} & & $-0.106^{\mathrm{a}}$ & \\
\hline & & $(0.0571)$ & \\
\hline \multirow[t]{2}{*}{ Numldio $_{t-1}$} & & & $-0.0699^{\mathrm{a}}$ \\
\hline & & & $(0.0414)$ \\
\hline \multirow[t]{2}{*}{ Size $_{t-1}$} & $0.182^{c}$ & $0.187^{c}$ & $0.187^{c}$ \\
\hline & $(0.0301)$ & $(0.0300)$ & $(0.0300)$ \\
\hline \multirow[t]{2}{*}{$A B S_{-} D A_{t-1}$} & $1.025^{\mathrm{b}}$ & $1.010^{\mathrm{b}}$ & $1.005^{\mathrm{b}}$ \\
\hline & $(0.409)$ & $(0.409)$ & $(0.409)$ \\
\hline \multirow[t]{2}{*}{$R O A_{t-1}$} & $1.669^{c}$ & $1.601^{c}$ & $1.601^{c}$ \\
\hline & $(0.563)$ & $(0.563)$ & $(0.564)$ \\
\hline \multirow[t]{2}{*}{$\operatorname{LeV}_{t-1}$} & -0.279 & -0.264 & -0.261 \\
\hline & $(0.182)$ & $(0.182)$ & $(0.182)$ \\
\hline \multirow[t]{2}{*}{ Dturn $_{t-1}$} & 0.124 & 0.122 & 0.127 \\
\hline & $(0.142)$ & $(0.139)$ & $(0.138)$ \\
\hline \multirow[t]{2}{*}{$S t d W_{t-1}$} & 2.258 & 2.601 & 2.529 \\
\hline & $(2.116)$ & $(2.118)$ & $(2.115)$ \\
\hline \multirow[t]{2}{*}{$M B_{t-1}$} & $0.0827^{c}$ & $0.0864^{c}$ & $0.0857^{c}$ \\
\hline & $(0.0195)$ & (0.0196) & $(0.0196)$ \\
\hline \multirow[t]{2}{*}{$S O E_{t-1}$} & $-0.299^{c}$ & $-0.290^{c}$ & $-0.292^{c}$ \\
\hline & $(0.0639)$ & $(0.0641)$ & $(0.0641)$ \\
\hline \multirow[t]{2}{*}{$\operatorname{Top}_{t-1}$} & -0.00180 & -0.00185 & -0.00181 \\
\hline & $(0.00205)$ & $(0.00204)$ & $(0.00205)$ \\
\hline \multirow[t]{2}{*}{ Independent $t_{t-1}$} & 0.142 & 0.159 & 0.187 \\
\hline & $(0.492)$ & $(0.492)$ & $(0.492)$ \\
\hline \multirow[t]{2}{*}{ Constant } & $-4.432^{c}$ & $-4.540^{c}$ & $-4.546^{c}$ \\
\hline & $(0.745)$ & $(0.746)$ & $(0.746)$ \\
\hline IND & Yes & Yes & Yes \\
\hline No. of obs. & 2324 & 2324 & 2324 \\
\hline
\end{tabular}

Notes. ${ }^{\mathrm{a}}{ }^{\mathrm{b}}{ }^{\mathrm{a}}$ and ${ }^{\mathrm{c}}$ represent the significance levels of $10 \%, 5 \%$, and $1 \%$, respectively 
Table 7 CAMs, shareholding of institutional investors, and crash risk

\begin{tabular}{|c|c|c|c|c|}
\hline \multirow[b]{3}{*}{ Variable } & (1) & (2) & (3) & (4) \\
\hline & \multicolumn{2}{|c|}{ Group of high proportion } & \multicolumn{2}{|c|}{ Group of low proportion } \\
\hline & NCSKEW & DUVOL & NCSKEW & DUVOL \\
\hline \multirow[t]{2}{*}{ CAM_TREAT } & 0.111 & 0.133 & -0.455 & -0.297 \\
\hline & $(0.187)$ & $(0.135)$ & $(0.584)$ & $(0.431)$ \\
\hline \multirow[t]{2}{*}{ CAM_YEAR } & -0.0222 & -0.00604 & $-0.247^{c}$ & $-0.105^{a}$ \\
\hline & $(0.0826)$ & (0.0599) & $(0.0807)$ & $(0.0605)$ \\
\hline \multirow[t]{2}{*}{ TREAT.YEAR } & $-0.498^{b}$ & $-0.354^{b}$ & 0.364 & -0.0415 \\
\hline & $(0.245)$ & $(0.178)$ & $(0.796)$ & $(0.591)$ \\
\hline \multirow[t]{2}{*}{ Size $_{t-1}$} & $0.102^{c}$ & $0.0756^{c}$ & $0.140^{c}$ & $0.108^{c}$ \\
\hline & $(0.0376)$ & $(0.0272)$ & $(0.0416)$ & $(0.0305)$ \\
\hline \multirow[t]{2}{*}{$A B S \_D A_{t-1}$} & 0.409 & 0.139 & 0.136 & 0.0623 \\
\hline & $(0.449)$ & $(0.325)$ & $(0.479)$ & $(0.354)$ \\
\hline \multirow[t]{2}{*}{$R O A_{t-1}$} & $1.180^{\mathrm{a}}$ & $1.011^{\mathrm{b}}$ & -0.482 & 0.178 \\
\hline & $(0.670)$ & $(0.490)$ & $(0.718)$ & $(0.527)$ \\
\hline \multirow[t]{2}{*}{$\operatorname{LeV}_{t-1}$} & 0.168 & 0.0621 & $-0.409^{b}$ & -0.222 \\
\hline & $(0.207)$ & $(0.151)$ & $(0.202)$ & $(0.148)$ \\
\hline \multirow[t]{2}{*}{ Dturn $_{t-1}$} & -0.0470 & -0.0110 & 0.0320 & 0.0249 \\
\hline & $(0.0439)$ & $(0.0318)$ & $(0.0402)$ & $(0.0298)$ \\
\hline \multirow[t]{2}{*}{$S t d W_{t-1}$} & $4.868^{c}$ & $3.950^{c}$ & $6.668^{c}$ & $4.354^{c}$ \\
\hline & $(1.716)$ & $(1.248)$ & $(1.729)$ & $(1.276)$ \\
\hline \multirow[t]{2}{*}{$M B_{t-1}$} & $0.0904^{c}$ & $0.0580^{c}$ & 0.0216 & 0.0236 \\
\hline & $(0.0200)$ & $(0.0144)$ & $(0.0215)$ & $(0.0158)$ \\
\hline \multirow[t]{2}{*}{$S O E_{t-1}$} & $0.140^{\mathrm{b}}$ & $0.103^{b}$ & $0.150^{\mathrm{a}}$ & 0.0848 \\
\hline & $(0.0693)$ & $(0.0502)$ & $(0.0769)$ & $(0.0560)$ \\
\hline \multirow[t]{2}{*}{ Top $1_{t-1}$} & 0.000223 & -0.000326 & $-0.00585^{b}$ & $-0.00331^{\mathrm{a}}$ \\
\hline & $(0.00224)$ & $(0.00163)$ & $(0.00240)$ & $(0.00176)$ \\
\hline \multirow[t]{2}{*}{ Independent $t_{t-1}$} & -0.712 & -0.390 & $1.320^{\mathrm{b}}$ & $1.040^{\mathrm{b}}$ \\
\hline & $(0.586)$ & $(0.426)$ & $(0.595)$ & $(0.434)$ \\
\hline \multirow[t]{2}{*}{ Constant } & $-3.208^{c}$ & $-2.470^{c}$ & $-4.278^{c}$ & $-3.415^{c}$ \\
\hline & $(0.845)$ & $(0.612)$ & $(0.944)$ & $(0.691)$ \\
\hline IND & Yes & Yes & Yes & Yes \\
\hline No. of obs. & 2000 & 1989 & 1962 & 1955 \\
\hline
\end{tabular}

Notes. ${ }^{\mathrm{a}},{ }^{\mathrm{b}}$ and ${ }^{\mathrm{c}}$ represent the significance levels of $10 \%, 5 \%$, and $1 \%$, respectively

CAMs, institutional investors' shareholding, and crash risk. We divide the full sample into two groups of high proportion and low proportion of institutional investors based on the median of the proportion held by institutional investors in the same industry in the same year. The results show that the coefficient of the interactive term in the highproportion group is significantly negative, indicating that the new audit standard significantly mitigates the crash risk of firms with a high proportion of institutional investors. This effect, however, is not observed in the low-proportion group. This result confirms the above theoretical analysis to a certain extent, that CAMs produce a marked effect on crash risk mainly through institutional investors. Professional institutional investors integrate this incremental information into stock prices and reduce crash risk, while the role of individuals is relatively limited. 


\section{Robustness test}

To ensure robustness and reliability in our conclusions, we conduct the following robustness tests. Table 8 shows the results of five kinds of robustness tests. (1) We change the measure of crash risk, use $D U V O L$ as the explained variable, and perform the regression according to Eq.(4), obtaining the same result. (2) Referring to Wang and Wang (2019), we only use the observations in the treatment group as the sample

Table 8 Robustness test

\begin{tabular}{|c|c|c|c|c|c|}
\hline & $\begin{array}{l}\text { Change different } \\
\text { measure of crash } \\
\text { risk }\end{array}$ & $\begin{array}{l}\text { Test of before and } \\
\text { after the } \\
\text { implementation }\end{array}$ & $\begin{array}{l}\text { Placebo } \\
\text { test }\end{array}$ & $\begin{array}{l}\text { Exclude firms in } \\
\text { financial industry }\end{array}$ & $\begin{array}{l}\text { No } \\
\text { winsorizing }\end{array}$ \\
\hline Variable & DUVOL & NCSKEW & NCSKEW & NCSKEW & NCSKEW \\
\hline \multirow[t]{2}{*}{$\overline{\text { CAMDUM }_{t-1}}$} & & $-0.588^{\mathrm{a}}$ & & & \\
\hline & & $(0.321)$ & & & \\
\hline \multirow{2}{*}{ CAM_TREAT $T_{t-}$} & -0.00115 & & 0.0157 & -0.0501 & 0.0192 \\
\hline & $(0.123)$ & & $(0.161)$ & $(0.179)$ & $(0.173)$ \\
\hline \multirow[t]{2}{*}{$C A M_{-} Y E A R_{t-1}$} & -0.0470 & & $0.817^{c}$ & $-0.113^{b}$ & -0.0572 \\
\hline & $(0.0415)$ & & $(0.0593)$ & $(0.0571)$ & $(0.0563)$ \\
\hline \multirow{2}{*}{$\begin{array}{l}\text { TREAT.YEAR } \\
1\end{array}$} & $-0.326^{a}$ & & -0.269 & $-0.413^{a}$ & $-0.450^{a}$ \\
\hline & $(0.172)$ & & $(0.215)$ & $(0.243)$ & $(0.242)$ \\
\hline \multirow[t]{2}{*}{ Size $_{t-1}$} & $0.0846^{c}$ & -0.0271 & $-0.0817^{c}$ & $0.117^{c}$ & $0.0541^{b}$ \\
\hline & $(0.0202)$ & $(0.143)$ & $(0.0255)$ & $(0.0282)$ & $(0.0240)$ \\
\hline \multirow[t]{2}{*}{$A B S_{-} D A_{t-1}$} & 0.0617 & -3.803 & -0.0302 & 0.271 & 0.126 \\
\hline & $(0.239)$ & $(2.346)$ & $(0.274)$ & (0.329) & $(0.178)$ \\
\hline \multirow[t]{2}{*}{$R O A_{t-1}$} & 0.533 & -3.997 & -0.350 & 0.196 & 0.0251 \\
\hline & $(0.357)$ & (3.951) & $(0.430)$ & $(0.491)$ & $(0.170)$ \\
\hline \multirow[t]{2}{*}{$\operatorname{LeV}_{t-1}$} & -0.105 & 0.759 & -0.0148 & -0.173 & -0.0268 \\
\hline & $(0.105)$ & $(1.030)$ & $(0.129)$ & $(0.144)$ & $(0.129)$ \\
\hline \multirow[t]{2}{*}{ Dturn $_{t-1}$} & 0.0146 & 0.0501 & 0.00703 & 0.00605 & -0.00289 \\
\hline & $(0.0217)$ & $(0.145)$ & $(0.0302)$ & $(0.0300)$ & $(0.0260)$ \\
\hline \multirow[t]{2}{*}{$S t d W_{t-1}$} & $3.891^{c}$ & 7.765 & $3.844^{c}$ & $5.313^{c}$ & $5.493^{c}$ \\
\hline & $(0.889)$ & (8.004) & $(1.074)$ & $(1.226)$ & $(1.177)$ \\
\hline \multirow[t]{2}{*}{$M B_{t-1}$} & $0.0385^{c}$ & 0.481 & 0.0148 & $0.0539^{c}$ & 0.000882 \\
\hline & $(0.0106)$ & $(0.428)$ & $(0.0134)$ & $(0.0146)$ & $(0.00137)$ \\
\hline \multirow[t]{2}{*}{$S O E_{t-1}$} & $0.0854^{b}$ & -0.202 & $0.113^{\mathrm{b}}$ & $0.136^{c}$ & $0.125^{b}$ \\
\hline & $(0.0367)$ & $(0.370)$ & $(0.0450)$ & $(0.0508)$ & $(0.0506)$ \\
\hline \multirow[t]{2}{*}{$T o p 1_{t-1}$} & $-0.00191^{a}$ & -0.00595 & $\overline{-} .00119$ & -0.00242 & -0.00224 \\
\hline & $(0.00114)$ & $(0.0100)$ & $(0.00143)$ & $(0.00157)$ & $(0.00157)$ \\
\hline \multirow{2}{*}{$\begin{array}{l}\text { Independent } \\
t-\end{array}$} & 0.330 & -1.709 & 0.195 & 0.299 & 0.389 \\
\hline & $(0.301)$ & $(2.462)$ & $(0.363)$ & $(0.415)$ & $(0.403)$ \\
\hline \multirow[t]{2}{*}{ Constant } & $-2.737^{c}$ & 0.422 & 0.944 & $-3.620^{c}$ & $-2.214^{c}$ \\
\hline & $(0.455)$ & (3.670) & $(0.592)$ & (0.634) & $(0.544)$ \\
\hline IND & Yes & Yes & Yes & Yes & Yes \\
\hline No. of obs. & 3964 & 142 & 3903 & 3922 & 3962 \\
\hline
\end{tabular}

Notes. ${ }^{\mathrm{a}}{ }^{\mathrm{b}}{ }^{\mathrm{a}}$ and ${ }^{\mathrm{c}}$ represent the significance levels of $10 \%, 5 \%$, and $1 \%$, respectively 
to test whether there are differences among these firms before and after the implementation of the new audit standard. The explanatory variable CAMDUM is a dummy variable which equals 1 and 0 before and after the implementation, respectively. The other settings are the same as in Eqs. (4) and (5). The results show that the coefficient of CAMDUM is significantly negative, which is consistent with the result of the main test. (3) We assume that the implementation year of the new audit standard is delayed by one year, and the data from 2016 to 2017 are used for the placebo test; the result obtained in the main test disappears. (4) We exclude observations from the financial industry from our sample, and the results are consistent with those from the main test. (5) The data are directly regressed without any winsorizing, and we obtain the same results as in the main test.

\section{Conclusion}

This study discusses the impact of CAMs on firm-specific crash risk, with the following main conclusions. First, the disclosure of CAMs significantly mitigates crash risk, which reflects the importance of implementing the new audit standard in improving corporate governance and stabilizing the capital market. Second, CAMs constitute negative incremental information. This is the core part of the mechanism through which CAMs alter investors' sentiment and decisions by changing the information environment and alleviating information asymmetry, which we have demonstrated to be true. Third, an increase in the number of CAMs in audit reports cannot significantly reduce crash risk. After eliminating industry-homogeneous CAMs, however, the number of CAMs begins to affect crash risk significantly, which implies that not all but only corporateidiosyncratic CAMs contain incremental information that essentially increases the amount of information in audit reports. Finally, we can only observe the inhibitory effect of CAMs on crash risk among firms whose shareholders consist of a high proportion of institutional investors, which indicates that the information in CAMs has a greater impact on institutional investors with less restrictions and less limited attention than individual investors.

Our conclusions may provide some enlightenment for report users, CPAs, and supervisors. For report users, audit opinions might be the only information that they could obtain from audit reports in the past. More detailed information would have been contained in audit working papers, which would not have been disclosed to users; therefore, they could not have fully understood the decision-making process of CPAs. With the new audit standard implemented, CAMs open up the "black box" of the entire audit process for users. On the one hand, more information can be used by report users to support their investment decisions but on the other, CAMs can also improve the authenticity and reliability of relevant information in audit reports. For audit practice, the higher disclosure standard for the audit report may encourage CPAs to be more cautious and to focus more attention on the process of disclosure in audit reports. However, CPAs still need to carefully consider the extent of information disclosure necessary to alleviate information asymmetry, narrow the information gap, and finally improve the usefulness of audit reports for decision-making; and so do other intermediaries in the capital market, such as rating agencies. Moreover, it has been shown that policymakers' and scholars' suspicions that some CAMs might become cliché and useless platitudes without any incremental information are indeed justified. The process 
of implementing the new audit standard may deviate from the core concept of the standard. A major concern to us is how to improve the quality of CAMs and audit reports so that more useful incremental information is made available, particularly for CPAs and accounting firms. In terms of supervision, relevant departments, including the CSRC, securities exchanges and the Chinese Institute of Certified Public Accountants, should provide active guidance and supervise the implementation of the new standard more effectively as necessary to bring the new regulations about CAMs into full play to maintain the order of the capital market and promote its sound development. A realization of these ideas would give full play to the professional ability of information intermediaries in the capital market, and further improve the pertinence of supervision and ultimately reduce supervision costs.

Regrettably, there are two main limitations in the study. First, the size of the treatment group is small and the formation process of the treatment group does not conform to the "random principle" required by the DID model, which may eventually affect the results. This is a common problem in the research design of all Chinese studies on CAMs. Second, the new standard has been in operation for four years, a relatively short time. Additionally, there are no lawsuits related especially to CAMs disclosure, wherein investors may clarify their legal responsibilities. Although the implementation of CAMs is a completely exogenous event, we may need to observe the outcome of relevant lawsuit cases in the future to realize a better result. Whether CAMs will continue to impact firm-specific crash risk and the whole Chinese capital market remains to be investigated in the future. However, we cannot deny that CAMs remain an important field where many different research directions can be explored in the future. For example, our study attempts to find specific CAMs that significantly affect stock price crash risk. Following this line of thinking, it is necessary to explore whether different categories and the number of CAMs have different effects on different issues (whether at company level or capital market level) when the relevant data are available. This kind of conclusion may be more targeted to solve a specific problem. Additionally, what factors determine the category and the number of CAMs disclosed by a CPA is also another research direction with great potential for future exploration.

\section{Abbreviations}

CAMs: Critical Audit Matters; CPAs: Certified Public Accountants; CSRC: China Securities Regulatory Commission; FRC: Financial Reporting Council; IAASB: International Audit and Assurance Standards Board; PCAOB: Public Company Accounting Oversight Board

Acknowledgements

Not applicable.

Authors' contributions

ZX raised research questions and, put forward suggestions on theoretical analysis and empirical research design. KZ conceived of this study, participated in theoretical analysis and the full empirical research design and drafted the manuscript. Both authors read and approved the final manuscript. 
Funding

Not applicable.

\section{Availability of data and materials}

Manually-collected data sharing is not applicable to this article as no datasets were generated or analyzed during the current study. If anyone is interested, please contact the author: Nicole9493@ruc.edu.cn.

\section{Ethics approval and consent to participate}

Not applicable.

\section{Consent for publication}

Not applicable.

\section{Competing interests}

The authors declare that they have no potential competing interests.

\section{Author details}

'Department of Finance, Business School, Renmin University of China, Room 0204, Chongde East Building in Renmin University of China, No.59 Zhongguancun Street, Beijing, Haidian District, China. ${ }^{2}$ Department of Finance, Business School, Renmin University of China, Room 0439, Pinyuan 3 Building in Renmin University of China, No.59

Zhongguancun Street, Beijing, Haidian District, China.

Received: 22 July 2020 Accepted: 8 February 2021

Published online: 12 April 2021

\section{References}

Asare, S. K., \& Wright, A. M. (2012). Investors', auditors', and lenders' understanding of the message conveyed by the standard audit report on the financial statements. Accounting Horizons, 26(2), 193-217.

Bekaert, G., \& Wu. G.(2000). Asymmetric volatility and risk in equity markets. Review of Financial Studies, 13(1), 1-42.

Blay, A. D., Geiger, M. A., \& North, D. S. (2011). The auditor's going-concern opinion as a communication of risk. Auditing: A Journal of Practice \& Theory, 30(2), 77-102.

Bleck, A., \& Liu, X. (2007). Market transparency and the accounting regime. Journal of Accounting Research, 45(2), 229-256.

Brasel, K., Doxey, M. M., Grenier, J. H., \& Reffett, A. (2016). Risk disclosure preceding negative outcomes: The effects of reporting critical audit matters on judgments of auditor liability. The Accounting Review, 91(5), 1345-1362.

Chan, W. S. (2003). Stock price reaction to news and no-news: Drift and reversal after headlines. Journal of Financial Economics, 70(2), 223-260.

Chen, L., \& Zhang, C. (2019). Critical audit matters and value relevance of earnings. Auditing Research, 3, 65-74.

Christensen, B. E., Glover, S. M., \& Wolfe, C. J. (2014). Do critical audit matter paragraphs in the audit report change nonprofessional investors' decision to invest? Auditing: A Journal of Practice \& Theory, 33(4), 71-93.

de Fond, M. L., Hung, M., Li, S., \& Li, Y. (2015). Does mandatory IFRS adoption affect crash risk? Accounting Review, 90(1), 265299.

Egeth, H., \& Kahneman, D. (1975). Attention and effort. The American Journal of Psychology, 88(2), 339.

Elizabeth, G., Miguel, M. M., Tatum, K. W., \& Maria, V. (2018). Consequences of adopting an expanded auditor's report in the United Kingdom. Review of Accounting Studies, 23(4), 1543-1587.

Fan, P. H. J., \& Wong, T. J. (2005). Do external auditors perform a corporate governance role in emerging markets? Evidence from East Asia. Journal of Accounting Research, 43(1), 35-72.

Fleak, S. K., \& Wilson, E. R. (1994). The incremental information content of the going-concern audit opinion. Journal of Accounting, Auditing and Finance, 9(1), 149-66.

FRC (Financial Reporting Council) (2013). International standard on auditing (UK and Ireland) 700-The independent Auditor's report on financial statements.

Gimbar, C., Hansen, B., \& Ozlanski, M. (2018). The effects of critical audit matter paragraphs and accounting standard precision on auditor liability. The Accounting Review, 91(6), 1629-1646.

Han, D., \& Zhang, J. (2018). Disclosure of key audit matters and Auditor's perception of audit responsibility. Auditing Research, $4,70-76$.

Hirshleifer, D. (2001). Investor psychology and asset pricing. The Journal of Finance, 56(4), 1533-1597.

Holderwebb, L. M., \& Wilkins, M. S. (2000). The incremental information content of SAS no. 59 going-concern opinions. Journal of Accounting Research, 38(1), 209-219.

Hutton, A. P., Marcus, A. J., \& Tehranian, H. (2009). Opaque financial reports, r-square, and crash risk. Journal of Financial Economics, 94(1), 67-86.

Jensen, M., \& Meckling, W. (1976). Theory of the firm: Managerial behavior, agency costs and ownership structure. Journal of Financial Economics, 3(4), 305-360.

Jiang, X., \& Yi, Z. (2013). Auditor industry specialization and stock price crash risk. China Accounting Review, 11(2), 133-150.

Jones, F. L. (1996). The information content of the auditor's going concern evaluation. Journal of Accounting and Public Policy, 15(1), 1-27.

Kachelmeier, S. J., Schmidt, J. J., \& Valentine, K. (2014). The disclaimer effect of disclosing critical audit matters in the auditor's report Unpublished working paper. University of Texas at Austin.

Kim, J., \& Zhang, L. D. (2012). Accounting conservatism and stock price crash risk: Firm-level evidence. Contemporary Accounting Research, 33(1), 412-441.

Klueber, J., Gold, A., \& Pott, C. (2016). Do key audit matters impact financial reporting behavior? Unpublished working paper. TU Dortmund University.

Menon, K.\& Williams, D. D. (2010). Investor reaction to going concern audit reports. Accounting Review, 85(6), $2075-2105$. 
PCAOB (Public Company Accounting Oversight Board). (2017). The auditor's report on an audit of financial statements when the auditor expresses an unqualified opinion and related Amendments to PCAOB Standards.

Raghunandan, K., \& Rama, D. V. (1995). Audit reports for companies in financial distress: Before and after SAS no. 59. Auditing, 14(1),50-63.

Tang, J. (2015). The evaluation and analysis on IAASB's audit report reform. Auditing Research, 1, 60-66.

Vinson, J., Robertson, J. C., \& Cockrell, C. (2018). The effects of critical audit matter removal and duration on jurors' assessments of auditor negligence. Auditing: A Journal of Practice \& Theory, 38(3), 183-202.

Wan, D. (2015). Audit fees and risk of stock price crash. Auditing Research, 6, 87-95.

Wang, H., Cao, F., \& Ye, K. (2015). Monitoring or tunneling? The proportion held by big shareholders and stock price crash risk. Management World, 2, 53-65.

Wang, M., \& Wang, D. (2019). New audit reporting and stock price synchronicity. Accounting Research, 1, 86-92.

Wang, Y., Xu, R., Wang, C., \& Yu, L. (2018). Can key audit matters enhance the communication value of the audit report? Accounting Research, 6, 86-93.

Xu, N., Jiang, X., Yi, Z., \& Xu, X. (2012). Conflicts of interest, analyst optimism and stock price crash risk. Economic Research Journal, 7, 127-140.

Xu, N., Li, X., Yuan, Q.. \& Chan, K. (2014). Excess perks and stock price crash risk: Evidence from China. Journal of Corporate Finance, 25, 419-434.

Xu, N., Yu, S., \& Yi, Z. (2013). Herd behavior of institutional investors and stock price crash risk. Management World, 7, 37-49.

Yang, M., Zhang, Q., \& Wang, Z. (2018). The effect of the implementation of new audit reporting standards on audit quality-Evidence from a quasi-natural experiment. Auditing Research, 5, 76-83.

Ye, K., Cao, F., \& Wang, H. (2015). Can Internal Control Information Disclosure Reduce Stock Price Crash Risk? Journal of Financial Research, 2, 192-205.

Ye, Y., Gao, H., \& Yang, X. (2019). The risk hidden in price surge: Evidence from Chinese stock markets. Chinese Journal of Management Science, 27(7), 11-22.

\section{Publisher's Note}

Springer Nature remains neutral with regard to jurisdictional claims in published maps and institutional affiliations.

\section{Submit your manuscript to a SpringerOpen ${ }^{\circ}$ journal and benefit from:}

- Convenient online submission

- Rigorous peer review

- Open access: articles freely available online

- High visibility within the field

- Retaining the copyright to your article

Submit your next manuscript at $\boldsymbol{\nabla}$ springeropen.com 